\title{
Médiaműveltség az USA-ban - egy bostoni példa
}

\author{
Dóra László*
}

Az Amerikai Egyesült Államokban is kiemelten fontos terület az iskolai oktatásban a médiamüveltség. A tengerentúlon az úgynevezett Thoman-modell az egyik leginkább elfogadott formája a médiamúveltség tanításának. Az amerikai iskolákban a modell javaslatai alapján a gyerekek gyakorlati feladatot is kapnak és ennek teljesitésén keresztül maguk is át tudják élni, hogyan müködik a tömegkommunikáció a gyakorlatban. A médiamüveltségnek már számos leírása ismert Európában. Az Egyesült Államokban is hasonlóan gondolkoznak róla, és van egy régóta ismert modellje is, amelyet az oktatásban használnak. Egy bostoni szakközépiskolában gyakorlat közben is megfigyelhetö, hogy a tengerentúlon mire helyezik a hangsúlyt a tömegkommunikáció értelmezése kapcsán.

Kulcsszavak: feladat, médiaműveltség, modell, USA, gyakorlat

\section{A médiamüveltség elméletétől a gyakorlati szemléletig}

A műveltség fogalmának meghatározó értelmezési kerete a társadalom és az azt létrehozó kultúra. A műveltség az adott kultúrában és adott időben meghatározott tudáskészlet, amely elengedhetetlen a mindennapi környezettel folytatott interakciók során. Ez a kulturálisan meghatározott tudásforma, relevánsan felhasználható képességeket, készségeket és ismereteket foglal magában. A formális és non-formális képzési rendszereken kívül is segíti az egyének fejlődését, naprakész és használható tudást jelent, és nem kötődik szorosan kontextushoz (Csapó, 2004). Ezért létezik a XXI. században többféle műveltség-fogalom, illetve múveltségi terület. Ezeken belül általános tájékozottságot, az összefüggések átlátását és alkalmazható tudást jelent egy tárgykör megértéséhez (Báthoryés Falus, 2001).

A médiaműveltség célja és jellemzője, hogy az információkat és az azokat hordozó kontextusokat a fogyasztók kritikusan használják és értelmezzék, amely segíti őket abban, hogy csökkenteni tudják a média látens befolyásoló hatását (Potter, 2013). A médiaműveltséggel szembeni fő követelmény a tömegkommunikáció által bemutatott reprezentációk lényegének felismerése, és lehetőség szerinti hasznos tudássá alakítása a kritikus befogadás, vagyis gondolkodási műveletek során (Alverman, Moon és Hagwood, 1999). Ezért kiemelt szempont megérteni, hogy a médiumokban milyen formákban jelenhetnek meg az adatok, információk (és azok feldolgozásával, tudatos elemzésével létrehozható tudás), illetve ezek hogyan keletkeznek (Koltay, 2009).

A média elemzés területén való jártasság ugyanakkor azt is jelenti, hogy műfajtól függetlenül a fogyasztók a tömegmédia információs folyamát saját javukra és ismeretszerzésükre (tanulásukra) használják fel, ezért szükséges a médiaismeretek integrálása az oktatási rendszerbe, úgy, hogy konkrét és tantárgyak feletti formában is használható tudást nyújtson (AKTI, 2010). A médiaműveltség - amely a tömegkommunikációban megjelenő tartalmakról szóló alapvető tudással, és annak gyakorlati elemzésével alakul ki - a média funkcióinak a megértésére, és kritikus elemzésére irányuló fejlesztés. A média formátumok és tartalmak összefüggéseinek megismeré-

* Egy szakképzéssel foglalkozó nemzetközi cég oktatási és kutatási igazgatója, valamint az (EMMI) Hagyományok Házában az oktatási tevékenységért felelő szakértő. E-mail: dora.laci@vipmail.hu 
se és az ezzel kapcsolatos tudás fejlesztése, a véleményalkotó képesség a megfelelő felhasználói magatartás szerves részét képezi (Hinés Subramaniam, 2009).

A médiaműveltség meghatározásában még egy lépést tesz egy másik szerzőpáros, amikor úgy fogalmaz, hogy a médiaműveltség azoknak az ismerteknek és készségeknek a halmaza, amely ahhoz szükséges, hogy a médiumokban megjelenő üzeneteket megértsük, és tudjuk, azok hogyan keletkeztek. Ahhoz azonban, hogy a tömegkommunikáció közlési formáját és a megalkotott reprezentációkat (nem első kézből származó információk megszerkesztését) megértse a közönség, ismernie kell a tömegkommunikáció munkáját ( Macedo és Steinberg, 2007). Shepherd (1993) három összetevőre bontotta ezt a médiaműveltséget. A kritikus megértés és értelmezés a fő cél a médiaműveltség iskolai kialakításakor, ez azonban csak akkor teljesül, ha a médiatermékek gyártásának folyamata ismert a tanulók számára, valamint a potenciális célközönség is aktív szerepet játszik az üzenetek értelmezésében.

A médiaoktatás mindezeket az egyszerű alapvetéseket elfogadja, de a gyakorlati megvalósítás terén, az elméleti megközelítéseken túl alkalmaznia kell a tanítás-tanulás folyamatában azt a szemléletmódot is, amelyik az iskolapadban is működik. A gyakorlatközpontú leírások - mint az előbbi megközelítés is - rávilágítanak az elméletek mögött látens formában jelen lévő elemzési módszerekre. Ezek, viszont ha nem is teljesen tiszta formában, már a médiapedagógiában megjelentek a 2000-es évek elején, a különféle didaktikai megfontolásokban (Hoffmann, 2003).

A médiamúveltség a pedagógiai gondolkodásban és feladatközpontú alkalmazásban tehát gyakorlatiasabban a médiaüzenetek értelmezése-elemzése-feldolgozása és kulturális kontextusba helyezése mint befogadó központú gyakorlati referencia. Ez magában foglalja a bemutatásból eredő hatásoknak, vagyis az érvelésnek, továbbá szimbolikus és kulturális kódoknak a felismerését - röviden a média gyártási struktúráját, főként az angol nyelvű szakirodalomban. Minden média válfaj tudatos értelmezésének kompetenciája az információk keletkezésének megértését jelenti a média működésének elemzésén keresztül (Celot és Tornero, 2008). A kritikus - és a tömegkommunikáció működését ismerő - befogadó tudja dekódolni és értékelni a közzétett üzeneteket, céltudatos és rutinszerű műveleteken keresztül, és képes elrugaszkodni a minimális tartalomelemzés szintjétől ( Burn és Durran, 2007). A médiaműveltség azért is igényel jelentősen nagyobb tudáskészletet, mert a médiaszövegek nagy részben nyitottak, céllal és funkcióval jönnek létre, és egyéni tapasztalatoktól függ az értelmezésük (Hobbs, 2006). Az elemzésnél a megalkotás célját, az alkalmazott technikát, és az információs elemek elrendezését is figyelembe kell venni (Key facts, 2003).

Ez, és a hasonló megfogalmazások hozták létre többek között azokat az egyszerü, a gyerekek nyelvén is érthető és egymásból logikusan következő lépésekre épülő kezdeti modelleket, amelyeket a médiapedagógia, különösen az Amerikai Egyesült Államokban, már az 1990-es évektől fogva fejleszt. A tengerentúlon jellemzően egyszerűen értelmezhető ábrákkal segítik a tanárok munkáját a didaktikai folyamat megtervezésében. Ezek a modellek lépésről-lépésre határozzák meg azokat a kérdésköröket, amelyeket az értelmezési folyamat során egymás után fel kell tenniük magukban a tanulóknak és meg kell rá adniuk a választ az elemzéshez. Először csak tanári útmutatással ismerkednek meg a folyamat lépéseivel, később pedig önálló, egyéni megfogalmazásban, majd pedig csoportos vitára bocsájtva a tömegkommunikációban bemutatott események elemzését ( $B l u m l e r e ́ s$ Gurevitch, 1995).

A médiaműveltség - alapjában (kritikai) kérdésekre építő - értelmezési lépcsőin keresztül jól érezhető az aktív használat és kritikus magatartás előtérbe kerülése. Ahogy Worsnop (1994) is megfogalmazta, a médiával kapcsolatos múveltség nem lehet tudattalan, és alapvető elméleti ismeretek nélkül sem értelmezhető, ezért a médiatanulmányok szerves részeként alakul ki. Az USA-ban alkalmazott modellek ezért az egyes értelmezési lé- 
pések fázisaként egy, a média működéséről szóló - alapvető elméleti ismereteket magában foglaló - tételmondatot fogalmaznak meg (Kress, 2003). Az oktatásban bővebb magyarázatként ezt szemléletes kérdések formájában bontják ki, mintegy elemzési egységekre redukálják. Az így megfogalmazott kérdések azonban nem eldöntendő válaszlehetőségeket tartalmaznak, hanem nyílt kérdések, ezért elengedhetetlen feltétel a megválaszolásukhoz a média működésével kapcsolatos gondolkodási tevékenység, amelyek az iskolai tanórák foglalkozásain kerülnek kialakításra (Martinés Madigan, 2006).

\section{Az amerikai médiamüveltség elméletének háttere}

Az Amerikai Egyesült Államokban mind a mai napig nincs egyértelmű meghatározás és pedagógiai koncepció a médiaműveltség értelmezéséről és gyakorlatáról. Minden államban másféle paradigmát és megközelítést tartanak előnyösnek a média értelmezéséről és iskolai használatáról (Christ, 2006).

Mint a legtöbb angol nyelvű területen, az amerikai filozófiai megközelítés is a kulturális tanulmányok alapvetését tartja alkalmazandónak. Ez a teoretikus szemléletmód azt szorgalmazza, hogy a tanulásban résztvevőket függetlenül az oktatás szintjétől és formájától - a tanárok próbálják meg bevonni a média megismerésének folyamatába, úgy, hogy kreatív, alkotó feladatokat adnak a diákoknak (Buckingham, 1998). Ez a módszer feloldja megfelelő alkalmazás esetében azt a dilemmát, amely a tanítás a médiával / tanítás a médiáról szemléletmódot és vitát övezi (Sholle és Denski, 1994). A cselekedtető tanulás egyúttal motiválja és aktivizálja a hallgatókat, valamint hatásos abban a tekintetben, hogy egy médiatartalom megalkotásán keresztül tulajdonképpen a felfedezéses tanulás erejére épít (Moser, 2010).

Az egyik legerősebb befolyásoló hatással rendelkező szervezet az USA-ban az 1989-ben alapított és Los Angeles-i székhelyű Media Literacy Center, amelyik médiaoktatással és a médiaműveltséggel foglalkozik. Ez a kutatócsoport már egy évvel a megalakulása után sürgette a médiamúveltség bevezetésének implementációját az államokban. Célkitűzésük egy olyan általános modell megalkotása volt, amely kortól és tudástól függetlenül képes rávezetni az oktatás alanyait a kritikus médiaértelmezésre (Chen, 2007).

Megfogalmazásuk szerint a médiaműveltség egy minden médiahasználó számára aktuális és élethosszig tartó elemzési módszert szorgalmaz, tekintet nélkül a tömegkommunikáció fajtájára vagy formájára ( Lankshear és Knobel, 2008). Az iskolában elsajátítható elméleti ismeretek mellett ezért kiemelt hangsúlyt kap a gyakorlat, amely a műsorok elemzését, illetve azoknak a szempontjait tartja elsődlegesnek.

Az amerikai médiaműveltség általános szemlélete a médiában megjelenő szövegek (információk), képek, és azok funkcióinak megértését (szórakoztatás, ismeretterjesztés, hírközlés), kezelni tudását jelenti. Ez magában foglalja a tömegkommunikáció speciális eljárásainak összességét, beleértve a látens tartalmakat, és azok kontextusait. A hatások és használat tekintetében a médiaműveltség hozzájárul a tudatos értelmezés pedagógiai fejlesztéséhez, és ezáltal egy élethosszig tartó szemléletmódot nyújt az oktatásban résztvevőknek (Oblinger és Oblinger, 2005). Az angol nyelvterületeken a médiaműveltségi felfogás ugyanakkor a hírközlő funkció jellemzőit és annak megértését tartja a legfontosabb kritériumnak. Ez az elmozdulás a filmes formanyelv (esztétikai és szórakoztató központú) elemzésétől az objektívnek tekintett műsorok elemzéséhez, hozzávetőlegesen az ezredfordulótól érvényesül egyre erőteljesebben (Share, 2008). Az okok döntő többsége az intenzív, az élet minden területére kiterjedő, tömegkommunikációs információáramoltatásra vezethető vissza. Ebben a tekintetben nem tesz különbséget a tengerentúli irányzat, hogy a felhasználók, akiknek a médiaműveltséghez értelmező-analitikus tudással rendelkezniük kell, milyen szocioökonómiai státusszal definiálhatóak (Hilliard, 2001). A pedagógiai gondolkodás szerint tehát mindenkinek egyaránt el kell sajátítania a médiaműveltség alapelemeit, éppen ezért 
olyan modellekkel dolgoznak, amelyek minimális tudáskészlettel, de fontos összefüggésekre rámutató, tevékenység-centrikus oktatást részesítenek előnyben.

Annak érdekében, hogy a tömegkommunikáció és a tantervek hatékonyan találkozzanak egymással, az Media Literacy Center összeállított egy olyan javaslatot, amely támpontokat ad a média oktatási intézményekben való használatára. Az általánosan megfogalmazott ajánlások között található, hogy a tömegkommunikációt a bemutatott tartalmak és médiaformátumok (objektív vagy szubjektív alkotások) alapján szükséges analizálni, és ezzel a diákokat a kritikus gondolkodásra nevelni. Fontos szempont, hogy változatos műfajú alkotásokkal, filmekkel, hírekkel ismertessék meg a tanítás során a hallgatókat, tekintettel a különböző érdeklődési körökre (Klein, 2012). Ennek során érdemes úgy bevonni és motiválni az oktatásban résztvevőket, hogy ők is készítsenek kisfilmeket, mert ezek a házi videók saját életterüket mutathatják be, nagyobb érdeklődést kiváltva. További előny lehet az is, hogy így a kisfilmek elkészítésének fázisait is maguk fedezik fel. Az ilyen alkotásokat lehetséges úgy interpretálni az iskolai munkában, mint a saját élményvilágot bemutató egyéni alkotásokat, látásmódot és kifejezési formát. Egy szabad beszélgetés során pedig lehetőség nyílik rá, hogy a csoportok kifejthessék véleményüket változatos témákban, amelyek feltehetően közelebb állnak hozzájuk, mint a professzionális alkotók munkái. Az egyéni vélemények mellett természetesen rá lehet vezetni a tanulókat arra is, hogy a megtekintett témakörrel kapcsolatban mintegy összefoglalják és szintetizálják a médiáról szóló tudásukat, megosztva azt a többi társukkal (Hobbs, 2007).

Egy általánosan elfogadott és jól működő technika az Egyesült Államokban az Elizabeth Thoman által megszerkesztett médiaműveltségi modell. Thoman alapítója volt a Media Literacy Center-nek, és a kutatóközpont felfogását tükröző, egymásra épülő gondolatkörből álló sémát alkotott az értelmezéshez. Az egyes lépcsőfokok segítenek a média üzeneteinek hatékony és konzekvens értelmezésében, mintegy bemutatva a tömegkommunikáció működésének folyamatát ( Giles, 2003). Maga a modell egyszerű, de nagyon fontos tudást és információkat közvetít a médiaműveltség kialakításához. A rendelkezésre álló tanórai időkeret és a médiapedagógus felkészültsége szerint, az egymásra lépcsőzetesen épülő kérdéskörökben akár nagyon mélyre is lehet merülni.

\section{A Thoman-féle médiamüveltségi modell}

Az amerikai médiakutatás és oktatás során öt szemléleti alappillérről szoktak beszélni, amelyet minden médiaformátum esetében azonosan lehet alkalmazni. Ezt a tengerentúlon a médiamúveltséggel azonosítják, amelyet kulcskompetenciaként fogalmaznak meg (Hanson, 2010). Thoman 1993-ban készült és öt pontba szedett összefoglalását a médiaműveltség alapjairól permanensen frissítették, hogy a XXI. század média kihívásainak is megfeleljen ( Thoman, 2003b). 


\section{Thoman-modell}

\section{1. múködést meghatározó kontextus}

\section{2. nézőpont, értékrendszer}

\section{3. médiaszabályok (szerkesztési elvek, lehetőségek)}

\section{4. konstruált médiaüzenetek (tartalmi mondanivaló elrendezése)}

\section{5. egyéni befogadás, eltérő értelmezés lehetősége}

\section{1. ábra: Az amerikai médiaértelmezés Thoman-modellje}

Minden értelmezési szinthez hozzátartozik egy alapelv, amelyet tudatosítani kell. Konkrétan, hogy a média üzenetei konstruáltak, tehát valamilyen rendezőelv alapján megszerkesztettek, ezért értékeket és nézőpontokat mutatnak be, amelyeket a közönség a személyes tapasztalatai alapján értelmez, és fogad be ( Thoman, 2003 a). Ez az alapelv jól rávilágít arra, hogy nem létezik kizárólag egyetlen és megbízható módszer a tömegkommunikációs üzenetek és azok tartalmának pontos definiálására. Egyúttal szabadságot jelent az értelmezésben, és egyéni jelentésstruktúrák és vélemények kialakítására ad lehetőséget a kommunikatív oktatási környezetben ( Kaplowitz, 2012).

A Thoman-modell első alappillére szerint, figyelembe kell venni a tömegkommunikációból származó hírek értelmezésénél a média szűkebb működési környezetét. Ezek olyan, mára már "klasszikusnak" számító fogalmakat tartalmaznak, mint a közszolgálati vagy kereskedelmi média (Chomsky és Herman, 2002). Lehet a hír pusztán érdekes és szenzációt keltő - ekkor a kereskedelmi média nézettségét növeli -, vagy nagy jelentőségü, amely sok embert érinthet, amely biztosan a közszolgálati hírek között fog szerepelni ( Graber, 1988). A következő pont szerint a média üzenetek minden egyes esetben tartalmaznak bizonyos - a készítő felfogása és tudása szerinti - értékrendszert. A híreknek azonban kötelező eleme az egymástól különböző nézőpontok bemutatása, ezért minden értelmezésnek helyet kell biztosítani a feldolgozás során. Ezeknek kiegyensúlyozottan kell szerepelniük, a lehető legjobb tájékoztatás érdekében (Corner, 1998). A harmadik szint szerint vannak további médiaszabályok, amelyek meghatározzák, hogyan működjön a hírek bemutatása. Ezek közül kiemelt szempont, hogy az elhangzó információk objektívek legyenek, ne tartalmazzanak érzelmi alapú elemeket. Ez utóbbiak ugyanis kedvezőtlen hatással lehetnek a megértésre, és szubjektív részleteket tartalmazhatnak (Carey, 1988). A negyedik egység fogalmazza meg, hogy a szöveg összeállításának a hír főbb körülményeinek és összefüggéseinek feltárásával magyarázatot kell adnia a bemutatott eseményre. Ezen túl a bemutatott történet előzményeit és következményeit egyaránt szükséges ismertetnie a teljes megértéshez. Ez önmagában meghatározza azt is, hogy egy esemény megjelenítése milyen mértékben lesz informatív (részletes) és pontos (Blumler, 1992). Az utolsó pont arra hívja fel a figyelmet, hogy minden fogyasztó egyéni jellemzőkkel, tapasztalatokkal és eltérő tudással rendelkezik, ezért az értelmezés során más-más jelentések jöhetnek létre. Mindez független lehet az alkotó szándékától és a bemutatás formájától egyaránt (Aitchisonés Lewis, 2003). 


\section{A médiamúveltség gyakorlata}

Egy tanulmányút során, amerikai ismerősöm meghívására érkeztem egy bostoni középiskolába, ahol részt vehettem egy médiaoktatási órán. A gyerekek az általam megtekintett tanórán mutatták be az elkészült feladatukat, amelyet a tanév során korábban kaptak. Azt volt a feladatuk, hogy egy, a lakóhelyükön történt - általuk fontosnak vélt - eseményt mutassanak be a többi társuk előtt. Ehhez kamerával (okostelefonnal stb.) le kellett filmezni az eseményt, és érthetővé tenni úgy, hogy szöveges magyarázatot, értelmezést adnak a képekhez. Ezt követően az anyagot - saját szándékuk szerint - meg is vághatták, vagy tetszésük szerint szerkeszthették, annak érdekében, hogy az esemény bemutatása ne nyúljon hosszabbra, mint egy híradós tudósítás. Ez a feladatleírás a gyakorlatközpontú alkalmazásra koncentrál, és kreatív kihívás elé állítja a tanulókat. Egyúttal magában süríti a modern technológiák használatát, amely izgalmassá teszi az oktatást, valamint az egyéni választás szabadságát a feladat kivitelezésében, továbbá az önkifejezést az alkotáson keresztül. Mindezt kreatív iskolai munkaként élik meg a tanulók (Longhurst, 2007).

A feladatok elkészítése folyamatosan történt, és minden héten a médiaismeret óra keretében egy-egy hallgató által elkészített anyagot mutattak be. A projektoros vetítés után a nézőközönség megbeszélte a kisfilmet, miközben a hír készítője csak figyelte a reakciókat és felvetéseket. Ennek a médiaműveltségi feladatnak az értelmezése során a Thoman-modell leírásában pontosan fordított sorrendben haladnak a tanulók. Ez a folyamat azt mutatja be, ahogy a nézők deduktív módon fejtik meg a bemutatott anyagok hatásait, illetve ahogy a bemutatás korlátait elemzik. Az így létrejött sokféle hozzászólás az ötödik pontban megfogalmazott egyéni látásmódok miatt alakul ki. Ezek a változatos, egyéni megjegyzések az egyes órák során mind segítenek megértetni a kisfilmet készítő fiatalokkal, hogyan lehetséges egy médiaesemény többféle jelentésének vagy értelmezésének a kialakulása (Giles, 2003).

A fordított sorrend okait természetesen az elméleti órák keretében előre megbeszélik a tanulók, és önállóan, szinte tanári irányítás nélkül haladnak. Ebben a pontban kezdődik a médiával kapcsolatos önálló és egyéni témakifejtés, a reflektálás a média által bemutatott eseményekre, amely kiemelt szempont a tömegkommunikációról való gondolkodás során. A csoportos munka abban is segít, hogy a deduktív értelmezés során a résztvevők megértsék azt a folyamatot, amelyet a média alkalmaz, és a nézőpontbeli különbséget, amely a befogadók és a műsorszámot készítők eltérő gondolatmenetében érhető tetten (Manning, 2001).

Elsőként - a modellben a negyedik pont szerint - megbeszélik a hallgatók, hogy a megtekintett esemény érthető volt-e. A hír egyes elemei magyarázatot adtak-e a bemutatott esetre, és az azok közötti ok-okozati öszszefüggés logikus történetet mesélt-e el. Ehhez a ponthoz tartozik az előzmények és következmények számbavétele is, amelyek szintén a bemutatás logikáját tükrözik, és segítenek megérteni a hírt. Értékelik azt is, hogy megfelelő információmennyiséget kaptak-e a bemutatás során, vagy akadt-e olyan részlet, amelyet nem tisztázott megfelelő mértékben a kisfilm alkotója, ezért pontosításra szorulna. Fontos megérteni, hogy ezek a kérdések nem csupán rövid eldöntendő kérdéseket takarnak, hanem egy-egy gondolatsort, ahol az egyes kérdésekre adott válaszok vezetik a gyerekek gondolatmenetét, valamint következetesen és szorosan épülnek egymásra. $A$ nézetek és hozzászólások következtében a gyerekek azt is megtanulhatják a tanári irányítás mellett, hogy milyen változatos értelmezéseket, gondolati sémákat, emlékeket vagy éppen egyéni előzetes ismereteket hoznak felszínre (McGuigan, 2006). A tanórán a médiapedagógus ezt úgy magyarázta el a gyerekeknek, mint egy szövegértelmezési feladatot, amelynek a végén találhatóak a kérdések, és ezek közül néhányat csak következtetéssel lehetne megválaszolni. Ugyanakkor a kérdések segítik a szöveg tartalmi mondanivalójának és elrendezésének a hangsúlyos részeit is feltárni. 
Ezután kerítenek sort arra, hogy a harmadik pont alapján megvizsgálják az információkat az objektivitás szempontjából. Ha találnak olyan részt, amelyik érzelmi megközelítést vagy álláspontot foglal magában, megpróbálják kitalálni, ez vajon hogyan és milyen mértékben lehet félrevezető a fogyasztók számára. Természetesen segítenek abban a társuknak, milyen módon lenne szükséges átfogalmazni és átszerkeszteni a hírt, hogy a zavaró tényező ne szerepeljen benne. Ez az egyik legfontosabb lépés, mert itt kell elsajátítaniuk a résztvevőknek, hogyan semlegesítsék a média egyik leginkább elterjedt, és - többek között - a pedagógia és pszichológia által is hangsúlyozott hatását. A média érzelmileg bevonó képi és hanghatásait, valamint a tartalom ezektől független elkülönítését ebben a fázisban értik meg a hallgatók (Newcomb, 2000). A bemutatókon ennél a résznél időznek a legtöbbet a gyerekek, és itt szükséges a tanárnak beleavatkoznia ez egyébként gördülékeny elemzésbe.

A második pontnál javaslatot tehetnek arra, hogy lehetséges lett volna-e más szempontot találni a bemutatásra, illetve hogy egyenlő időt kaptak-e az eltérő értelmezések. Itt elemzik a kamerafelvételen látható képeket, vajon miért abból a szemszögből (kameraállásból) mutatja be az eseményt, illetve hogyan lehetett volna ezen javítani. Továbbá értékelik, hogy a képek és szöveg viszonya megfelelő-e, a szöveg alátámasztja, kiegészíti-e a képen látottakat - így segítve a megértést -, vagy éppen nincs szinkronban a kettő és nem érthető az egyidejű képek és a szöveg jelentése. Ilyen esetben megpróbálják a szöveget olyan formába önteni, hogy a látott eseményhez igazítják a hosszát. Az egyéni látásmódok, értelmezések és a kreativitás nagy hangsúlyt kap a második pontnál. Azok, akik eddig csak passzív, - de értelmező - szemlélői voltak a vetített anyagnak, most tulajdonkép pen egy képzeletbeli alkotófázisba lépnek át. Ennek során mintegy újfajta szemléletet adnak az eseménynek, és szintén újfajta - egyéni - látásmódot valamint értelmezést adnak hozzá egy korábban általuk nem ismert jelenséghez (Ormiston, 2011). Ez a lépés az a mérföldkő, amikor a tanulók teljes mértékben átélik a médiában dolgozók helyzetét, és a munkafolyamatot, amely során létrehozzák, újraalkotják a hírközlésben látott eseményt. Eközben jönnek rá, hogy milyen korlátozó tényezők lépnek fel egy hír elkészítése és bemutatása kapcsán.

Az első ponthoz érkezve kísérletet tesznek arra a vetítésen résztvevők, hogy meghatározzák miért ezt az eseményt dolgozta fel az osztálytársuk. Ez megmutatja, hogy milyen szempontból volt fontos - számára - a téma. Megvitatják azt, az előbbi kritériumokat figyelembe véve, hogy a hír közszolgálati médiumban, vagy inkább kereskedelmi csatornán szerepelhetne-e. Természetesen megindokolják az álláspontjukat a hír érdekességére és jelentőségére vonatkozóan. A nézőpont és értékrendszer tudatosítása itt a cél, hiszen a szerkesztési elvek és szabályok során az időkorlát miatt választania kell az alkotónak, hogy mit és milyen mélységig mutat be, hogyan képes a tartalmat összefoglalni röviden és közérthetően. Ez a választás határozza meg, hogy az általa készített alkotás a nézők értelmezésében végső soron milyen értékítéletet jelenít meg. Vagyis megmutatja, hogy egy másik - hasonló életkorú, képzettségű, és szociokulturális háttérrel rendelkező - személy hogyan látja és értelmezi az őt körülvevő világot (Richardson, 2006).

Mikor az egész folyamat elemzésének végére értek, a film készítője akkor kap csak szót. A felvetett ötletekre és javaslatokra reflektálva elmagyarázza a saját álláspontját. Részletesen kitér arra, hogy mit és miért alkalmazott úgy, ahogy az látható/hallható volt. Elmondja, melyek voltak a korlátozó tényezők, amelyek nem tették lehetővé azokat az észrevételeket, amelyeket a társai másként készítettek volna el. A legtanulságosabb momentum ez, az általam látott órán ebben a részben volt a legcsendesebb az osztály, amikor naivan rácsodálkoztak azokra a körülményekre, amelyeket nem is sejtettek. Ez a fázis mutatja meg, hogy milyen apró és lényegtelennek tűnő körülmények befolyásolhatják egy elkészített hír feldolgozási folyamatát, illetve a látottak szemszögét és értelmezési keretét. Ez a hallgatóközpontú gyakorlat végig követi a tömegkommunikációs hírek készítésének lépéseit, egészen a témaválasztástól kezdve a fogyasztók értelmezéséig. Az egész folyamat és feladat lényege az, hogy reprezentálja a tanulók számára, hogy hányféle nézőpont és értelmezés jöhet létre egy egyszerű ese- 
mény bemutatása során. Ekkor érthetik meg igazán, hogy a média a mindennapi működése során milyen reakciókat és hatásokat képes kiváltani a nézőkből, illetve hogyan is működik valójában a hírközlés.

\section{Szakirodalom}

1. Aitchison, J. \& Lewis, D. M. (2003, ed.): New Media Language. Routledge, London.

2. AKTI (2010): Tanulmány a médiajártasság szintjeinek értékelési kritériumairól. AKTI, Budapest.

3. Alverman, D. E., Moon, J. S. \& Hagwood, M. C. (1999): Popular Culture in the Classroom: Teaching \& Researching Critical Media Literacy. International Reading Association, Newark.

4. Báthory Zoltán és Falus Iván (2001, szerk.): Tanulmányok a neveléstudomány köréböl. Osiris Kiadó, Budapest.

5. Blumler, J. G. (1992, ed.): Television \& the Public Interest. SAGE, London.

6. Blumler, J. G. \& Gurevitch, M. (1995): The Crisis of Public Communication. SAGE, London.

7. Buckingham, D. (1998): Media Education in the UK. Journal of Communication. 1. 35 -43.

8. Burn, A. \& Durran, J. (2007): Media Literacy in Schools. Practise, Production and Progression. Sage, London.

9. Carey, J. (1988): Communication as Culture. Routledge, London.

10. Celot, P. \& Tornero, J. M. P. (2008): Media Literacy in Europe. EAVI, Brussels.

11. Chen, G. M. (2007): Media (Literacy) Education in the United States. China Media Research. 3. 87-103.

12. Chomsky, N. \& Herman, E. S. (2002): Manufacturing Consent: The Political Economy of the Mass Media. Pantheon Books, New York.

13. Christ, W. G. (2006): Assessing Media Education. Lawrence Erlbaum, Mahwah.

14. Corner, J. (1998): Studying Media: Problems of Theory and Methods. Edingburgh University Press, Edinburgh.

15. Csapó Benő (2004): Tudás és iskola. Műszaki Könyvkiadó, Budapest.

16. Giles, D. C. (2003): Media Psychology. Lawrence Erlbaum Associates, New Jersey.

17. Graber, D. A. (1988): Processing the News: How People Tame the Information Tide. Longman, New York.

18. Hanson, R. E. (2010): Mass Communication: Living in a Media World. CQ Press, Thousand Oaks.

19. Hilliard, R. L. (2001): Media Education and America's Counter-culture Revolution. Ablex Publishing, Westport.

20. Hin, L. T. W. \& Subramaniam, R. (2009): Handbook of Research on New Media Literacy at the K-12 Level: Issues and Challenges. IGI Global, Hershey.

21. Hobbs, R. (2006): Reconceptualizing Media Literacy for the Digital Age. In: Martin, A. \& Madigan, D. (ed.): Literacies for Learning in the Digital Age, Facet Press, London. 99-109.

22. Hobbs, R. (2007): Reading the Media. Teachers College Press, New York.

23. Hoffmann, B. (2003): Medienpädagogik. Eine Einführung in die Theorie und Praxis. Ferdinand Schöningh, Paderborn.

24. Kaplowitz, J. R. (2012): Transforming Information Literacy Instruction Using Learner-Centered Teaching. Facet, London.

25. Key facts (2003): Media Literacy. The Henry J. Kaiser Family Foundation, Boston. URL: http://www.kff.org/entmedia/upload/Key-Facts-Media-Literacy.pdf Utolsó letöltés: 2014. június 6.

26. Klein, C. (2012): Mediale Vorbildkompetenz. Beltz-Juventa, Basel.

27. Koltay Tibor (2009): Médiamúveltség, média-írástudás, digitális írástudás. URL: http://www.mediakutato.hu/cikk/2009_04_tel/08_mediamuveltseg_digitalis_irastudas Utolsó letöltés: 2014. június 6. 
28. Kress, G. (2003): Literacy in the New Media Age. Routledge, New York.

29. Lankshear, C. \& Knobel, M. (2008, ed.): Digital Literacies: Concepts, Policies and Practices. Peter Lang, New York.

30. Longhurst, B. (2007): Cultural Change and Ordinary Life. Open University Press, Maidenhead.

31. Macedo, D. \& Steinberg, S. (2007, ed.): Media Literacy: A Reader. Peter Lang, New York.

32. Manning, P. (2001): News and News Sources. A Critical Introduction. Sage, London.

33. Martin, A. \& Madigan, D. (2006): Digital Literacies for Learning. Facet Publishing, London.

34. McGuigan, J. (2006): Modernity and Postmodern Culture. Open University Press, Maidenhead.

35. Moser, H. (2010): Einführung in die Medienpädagogik: Aufwachsen im Medienzeitalter. VS Verlag für Sozialwissenschaften, Wiesbaden.

36. Newcomb, C. H. (2000, ed.): Television: the Critical View. Oxford University Press, New York.

37. Oblinger, D. G. \& Oblinger, J. L. (2005, ed.): Educating the Net Generation. Educause, London.

38. Ormiston, M. (2011): Creating a Digital-Reach Classroom: Teaching \& Learning in a Web 2.0 World. Solution Tree, Bloomington.

39. Potter, W. J. (2013): Media Literacy. Sage, California.

40. Richardson, W. (2006): Blogs, Wikis, Podcasts, and Other Powerful Tools for the Classroom. Corwin Press, California.

41. Share, J. (2008): Media Literacy is Elementary: Teaching Youth to Critically Read and Create Media. Peter Lang Publishing, New York.

42. Sheperd, R. (1993): Why Teach Media Literacy. Quadrant Educational Media Services, Toronto.

43. Sholle, D. \& Denski, S. (1994): Media Education and the Reproduction of Culture. Bergin \& Garvey, Westport.

44. Thoman, E. (2003a): Media Literacy - A Guided Tour of the Best Resources for Teaching. A Journal of Educational Strategies, Issues and Ideas. 6. 278-283.

45. Thoman, E. (2003b): Skills and Strategies for Media Education. URL: http://www.medialit.org/reading_room/pdf/CMLskillsandstrat.pdf Utolsó letöltés: 2014. június 6.

46. Worsnop, C. (1994): Screening Images: Ideas for Media Education. Wright Communications, Canada. 